\title{
Human Trafficking and Media Myths: Federal Funding, Communication Strategies, and Canadian Anti-Trafficking Programs
}

\author{
Ann De Shalit \\ Ryerson University \\ Robert Heynen \\ York University \\ Emily van der Meulen \\ Ryerson University
}

\begin{abstract}
This article looks at debates over human trafficking by considering the linkages between federal funding, media myths, and non-governmental organization (NGO) activities and by examining the textual and visual content of NGO websites. By highlighting the ways in which NGOs echo government communication strategies, we argue that these debates are constrained not only by the current political terrain, but also by an ingrained and problematic anti-trafficking discourse. Further, we interrogate the language and emotive appeals of NGOs that receive federal funding for anti-trafficking programming through the exploration of counter-discourses developed by both scholars and independent organizations that are critical of dominant narratives and policies. We conclude by suggesting that alternative narratives and media strategies are needed for the development of more nuanced and authentic conceptions of labour, migration, and sex work.
\end{abstract}

KEYWORDS Mass media; Human trafficking; Discourse analysis; Policy analysis; Visual communication; Anti-trafficking myths; Federal communication strategy

RÉSUMÉ Cet article examine les débats sur la traite des personnes en considérant des liens entre le financement fédéral, les mythes des médias, et les organisations nongouvernementales (ONG) et en examinant le contenu textuel et visuel des sites web des ONG. En analysant la façon dont les activités des ONG reflètent les stratégies de communication du gouvernement, nous soutenons que ces débats sont limités non seulement par le terrain politique actuel, mais aussi par un discours anti-trafic enraciné et problématique. En outre, nous interrogeons le langage et les appels émotifs des ONG qui reçoivent des fonds du gouvernement fédéral pour la programmation pour la lutte contre la traite à travers l'exploration de contre-discours développés par les universitaires et les organisations indépendantes critiques de récits et politiques dominants. Nous concluons en

Ann De Shalit is a PhD Candidate, Policy Studies Program, Ryerson University. Email: adeshali@ryerson.ca . Robert Heynen is Assistant Professor, Department of Communications, York University. Email: rheynen@yorku.ca . Emily van der Meulen is Assistant Professor, Department of Criminology, Ryerson University. Email: evandermeulen@ryerson.ca .

Canadian Journal of Communication Vol 39 (2014) 385-412

(C)2014 Canadian Journal of Communication Corporation 
suggérant que les récits alternatifs et des stratégies médiatiques sont nécessaires pour le dévelopment des conceptions plus nuancées et authentiques du travail, de la migration, et du travail du sexe.

MOTS CLÉS Médias de masse; Traite des êtres humains; Analyse de discours; Analyse politique; Communication visuelle; Mythes anti-traite; Stratégie de communication fédérale

\section{Introduction}

Concern over human trafficking has seen a strong resurgence in recent years. Described by the Government of Canada as "one of the most heinous crimes imaginable" (Public Safety Canada, 2012, p. 1), anti-trafficking narratives deploy shocking and highly emotive language and imagery in constructing "victims" in need of saving. This anti-trafficking discourse has underwritten significant legislative changes, in Canada, with the inclusion of Section 118 in the Immigration and Refugee Protection Act (IRPA) in 2002 and the implementation of Sections 279.01 to 279.04 in the Criminal Code of Canada in 2005 (see Government of Canada, 2005), as well as in other countries. The publication of the United Nations Protocol to Prevent, Suppress and Punish Human Trafficking, Especially Women and Children, Supplementing the United Nations Convention against Transnational Organized Crime ("Trafficking Protocol") in 2000 provides an important framework for national responses; however, those responses are not uniform. In the Canadian case, the Criminal Code and the IRPA diverge from the Trafficking Protocol in that their provisions can be applied to individuals, not solely organized criminal groups (Sikka, 2009). Further, while the Trafficking Protocol requires evidence of border crossing for the purpose of exploitation, the IRPA only focuses on coercive means of transportation, opening the door to ideas of "domestic" trafficking. Finally, the Criminal Code also does not require the "victim" to have been deceived at all (Sikka, 2009). The latter stands in glaring contrast to the internationally accepted definition of human trafficking, which is concerned with a person's consent or lack thereof. As this articles argues, these legislations, especially the provisions set out in the Criminal Code that allow law enforcement agents to deem someone "trafficked" even if they do not identify as such, have concretized an emotional anti-trafficking discourse that typically coincides with stricter immigration controls and enhanced criminalization and surveillance of migrant labour and the sex industry.

The affecting language and imagery surrounding human trafficking is widespread, having emerged, in part, out of concerted media campaigns by both governments and non-governmental organizations (NGOs). This article contends that meaningful debate over the nature of trafficking and the implications of state policies has been constrained by the stark ways in which trafficking has been framed in the media and elsewhere. Media representations of trafficking, trafficking victims, and the trafficker produce forms of visibility and invisibility that draw on broader forms of representation of migrants and Indigenous peoples, particularly women, in news coverage, film, documentaries, and photographs (England, 2004). Anti-trafficking discourses tend to incorporate a number of common themes in this respect. First, it is often argued that "[h] uman trafficking is a modern form of slavery" (People's Law School, 2010, p. 1). Second, as evidenced by one anti-trafficking organization's claim that "[e]ach year 2 
million children are exploited in the global commercial sex trade" (NASHI, 2013, para. 3), human trafficking is often conflated with sex work and prostitution, and tied to child exploitation and sexual abuse. Finally, media narratives and images build up a depiction of the trafficker that enables a stark vision of good and evil, exploited and exploiter, and in turn propels the desire to intervene to combat this scourge and "rescue" its victims. These are extremely powerful tropes that have been taken up by a range of organizations; yet, these narratives and their impact on policy formation are rarely interrogated. Whether deliberately or inadvertently, we argue that these antitrafficking discourses foster support for potentially regressive political agendas and approaches to questions of labour and migration.

Our focus here is on the ways in which government communication strategies intersect with those of NGOs engaged in anti-trafficking programming. Despite the often significant differences in their politics and perspectives, police, anti-prostitution feminists, religious groups, governments, and anti-trafficking NGOs all tend to reproduce dominant discourses. These often involve vague and undefined understandings of human trafficking based on highly speculative and wildly divergent estimates of its scope. State funding of anti-trafficking campaigns and NGOs tends to reinforce these discourses, channelling resources to groups whose positions align with that of the government, or directing resources to certain projects and not others. In our examination of websites of NGOs that receive federal government resources to engage in anti-trafficking programming, we find that there is a strong tendency for powerful sets of dominant narratives and images to be reinforced. Notions like "modern-day slavery," which evoke moral panics over "white slavery" from the early 190os, serve to paper over the significant political differences between different NGOs themselves, as well as between these NGOs and the government. Even while these organizations are advancing their own interests, they also participate in replicating the deeply embedded rhetorical power of dominant anti-trafficking tropes (Amar, 2009; Bernstein, 2007). In examining the websites of NGOs that receive federal anti-trafficking dollars, we thus find a reliance on narratives that promote a state approach to migration that relies primarily on policing and border security, as well as an enhanced surveillance of the sex industry.

We begin this article with an analysis of the construction of the human trafficking problem in Canada by looking at some of the broader narratives and myths circulating in the media. We then examine the federal government's approach to information management and their funding of anti-trafficking NGOs. Then, in the subsequent section, we examine the extent to which government conceptions of "human trafficking" and "trafficking victims" match those found in the textual and visual content of the websites of eighteen NGOs that receive federal funding to engage in anti-trafficking programming. On this basis, we argue that there is a strong correlation between the two, and that together they generate a powerful set of trafficking images and narratives. In tracing these out, we offer a critical analysis of the language and images used and their policy implications, while also noting instances where these NGOs challenged dominant discourses and government policies. In the final section, we examine counter-narratives developed by both scholars and independent NGOs critical of antitrafficking tropes and policies. Together, these analyses highlight the potentially detri- 
mental implications of anti-trafficking narratives and efforts for non-status peoples, migrant workers, sex workers, racialized women, and Indigenous women. Critical scholars and organizations have instead developed alternative discourses and media strategies to put forward arguments for more nuanced and evidence-based conceptions of labour and migration that challenge the security-based framework that dominates Canadian and international policy.

\section{Understanding the Canadian trafficking story: Victim narratives and media myths}

Conceptions of human trafficking in Canada often rely more on highly emotive and vague or contradictory rhetoric than on concrete evidence (Roots \& De Shalit, 2014). As in other areas, dominant discourses govern our conceptualization of and reaction to human trafficking by placing limitations on what can be thought, known, and said in relation to it (Hajer \& Laws, 2006). Michel Foucault's (1991a) notion of governmentality is useful here, especially in thinking about the dispersal of biopolitical forms of regulation, those that intervene at the micro-political level of the body, that are evident in the central role played by NGOs in elaborating conceptions of human trafficking. In relation to trafficking, it is especially his stress on the combination of pastoral, diplomatic-military, and police techniques that form "the governmentalization of the state" (Foucault, 1991b, p. 104) that is key. All of these different forms of power and knowledge are evident in our study, with media images, state policy, and forms of policing and security all playing crucial roles in cementing hegemonic approaches to trafficking. At the same time, as neo-Gramscian state theorists have noted (Jessop, 1990; Poulantzas, 1980), in focusing on the micro-physics of power, Foucault's approach risks downplaying the emergence of more structured forms of state or extra-state power, ranging from capitalist social forms to the systemic relations of gender or race. In the case of responses to human trafficking, we can see all of these structuring elements at play, in particular the erasure of gendered and racialized global relations of labour in hegemonic discourses. Jessop's (1990) work, which draws on but also critiques Foucault, thus stresses that we need to understand the state as relational, and as embodying a "means of reducing the complexity of social relations and fixing them in a temporary, provisional and always unstable way" (p. 246). This approach, he argues, also brings into view those "alternative interpretations and strategies" that are marginalized in the process (p. 246); we return to precisely these alternatives at the end of the article.

Like most stories, the dominant human trafficking narrative has "a protagonist, an antagonist, and a difficult challenge to overcome" (Edwards, 2010, p. 886). The trafficker, of course, is the adversary, and the government plays the leading hero's role, enacting a kind of paternalism that Foucault (1991b) identifies as central to the history of governmentalization. In her analysis of the politics of "protection," Stiehm (1982) brings out this gendered dimension explicitly in arguing that government officials, who are most often men, make decisions about the use of force and its legal ramifications, often positioning themselves, the state, and most other men as protectors or defenders. Women become dependent on such protection, blocked from accessing political power, even while "women who are supposed to be protected know that they frequently are not. They also know that protectors are often a source of danger to the 
protected" (Stiehm, 1982, p. 367). As we shall see, dominant discourses frame the issue of trafficking as a hidden evil that requires both social attention (hence our focus on media campaigns) and legal action, producing a stark and simplified depiction of trafficking, trafficking victims, and traffickers that allows for selective comprehension, exaggeration, and misrepresentation of events (Gamson, 1992). At the same time, this gendered dynamic is strongly racialized, with Indigenous and racialized migrant women (sex working or not) understood as de facto in need of "saving" in Western rescue missions (Agustín, 2007; Doezema, 2001; Kempadoo, 2001). These master narratives are buttressed by a "rhetoric of abolition" (Soderlund, 2005, p. 65) that uses a binary division of captivity and freedom to urge the protection and rescue of women from sex work, exploitation, slavery, and trafficking (Soderlund, 2005).

The story does not end there, however, as the dominant trafficking tale offers a victim who is not only the object of protection, but also potentially the antagonist and a challenge that must be overcome. The victim/saviour dichotomy emphasized in anti-trafficking discourses is complicated by the common association of trafficking with sex work, and the construction of global sex workers through the Madonna/whore division that has been widely critiqued by feminists. This dichotomy justifies both a paternalistic saving and a potential criminalization of sex workers and/or women who are seen to be trafficked (Jeffrey, 2005). This criminalization also renders their experiences of violence and labour exploitation less visible (England, 2004), producing a tendency to discount the human rights of women involved in the sex trade. Feminized labour, more broadly, thereby risks being criminalized, while the often exploitative nature of that labour is frequently ignored (Bloch, 2003). As Cheng (2008) contends,

the tendency toward strengthening law enforcement and border control, as well as fortifying anti-immigrant policies and anti-prostitution agendas, serves to enhance the powers of the state and to divert attention from problems of unsafe migration and the larger-scale exploitation of unfree labor. (p. 16)

Human rights claims frequently centre on a victimization discourse, which tends to limit theorizing to a simple "savage" and "saviour" (Stanley, 2009). Victimhood discourses "mobilize and claim rights through this identification rather than through an appeal to justice," thus generating protection rather than power, and silence instead of expression (Aradau, 2003, p. 56). Discourses of victimization and rescue are particularly evident in the resurgence of colonial narratives in contemporary moves to "save" non-Western, racialized women. As Mohanty (1984) has argued, Western feminist efforts to absolve "third world" women from the violence they face often define them as "archetypal victims[,] freez[ing] them into 'objects-who-defend-themselves', men into 'subjects-who-perpetrate-violence', and (every) society into powerless (read: women) and powerful (read: men) groups of people" (p. 339). Thus, women and men are placed into ahistorical and dichotomous categories, "the victims and the oppressors" (Mohanty, 1984, p. 340). The idea of the "victim" grounding trafficking discourse has similarly resulted in rescue-driven responses that perpetuate patriarchal and colonial practices while, in fact, supressing the agency of those most affected by such efforts, 
namely, people with precarious migration status, migrant labourers, racialized women, and sex workers (Agustín, 2007).

The framing of trafficking through narratives of victims and saviours dominates media representations. It is in this respect that the overlapping perspectives offered by government and NGO "experts" in news reporting serve so strongly to limit perspectives on migration and to set a very narrow anti-trafficking agenda. These experts side overwhelmingly with the anti-trafficking victimization perspective. Benjamin Perrin, a recent special advisor and legal counsel to Prime Minister Stephen Harper, and Victor Malarek, senior reporter with CTV's investigative news show W Five, are prominent examples. Malarek is a supporter of one of the organizations reviewed below and is quoted on its website (NASHI, 2013). In their writing, both Perrin (2010) and Malarek $(2003,2009)$ rely heavily on stories and images of bondage, savages, sex slaves, and saviours that are prominent in anti-trafficking discourses. Malarek himself has made his name in part through his sensationalist reporting and books on sex trafficking, the area of trafficking that is most often represented in the media, as well as with a string of documentaries and films depicting the alleged problem. Countering this narrative, Arthurs (2012) argues in her critical study of the representation of trafficking in two such films, including the Canadian co-production Sex Traffic, that

we should let go of 'trafficked women' as a label and of charitable models of intervention which are structured in relation to idealized images of innocence and home as an anchor for a unitary and fixed identity. Constructing distant others as the objects of philanthropy denies their capacity as subjects who have agency. (p. 155)

Cheng (2008) echoes this proposition by suggesting that anti-trafficking efforts in the United States are often based on unrealistic dichotomies that depoliticize sex work and migration and further marginalize already disenfranchised groups.

Drawing on similar media representations, large-scale sporting events around the world, including Olympic Games and World Cups, have often crystalized fears over trafficking, with NGOs leveraging this visibility to promote their anti-trafficking campaigns (Lepp, 2013). The case of the 2010 Olympic and Paralympic Games in Canada provides a powerful example of the various anti-trafficking discourses detailed above, along with their potentially dangerous policy implications. In the lead up to the Games, for example, the Vancouver Observer reported on the Salvation Army's efforts:

They view the 2010 Vancouver Olympics as the biggest opportunity for them in decades. The Salvation Army is set to launch a huge campaign against trafficking during the Olympics because, 'God is bigger than VANOC' [the Vancouver Organizing Committee for the 2010 Olympic and Paralympic Winter Games]. (Wallace, 2010, para. 9)

Writing for the Winnipeg Free Press, Joy Smith (2010), Conservative Member of Parliament for Kildonan-St. Paul, Manitoba, who has been quite vocal about her antitrafficking and anti-sex work position, reported:

Similar to many other large sporting events where the demand for paid sex spikes, young women and girls were trafficked to Vancouver from 
across Canada to be sexually exploited for the gratification and profit of others. (Smith, 2010, para. 2)

Comparable panics have accompanied other large-scale sporting events. The 2010 World Cup in South Africa, for example, was preceded by expectations that some 40,000 extra sex workers would be "imported" into the country during the event, resulting in unprecedented numbers of trafficking victims (GAATW, 2011). This claim was repeated in the media on several occasions, sometimes inflated up to 100,000. These numbers were never substantiated and, in fact, not a single case of human trafficking was identified during the event, a detail rarely mentioned in the post-games media (GAATW, 2011).

In the case of the Vancouver Olympics, the Global Alliance Against Traffic in Women (GAATW) (2011), an NGO critical of dominant anti-trafficking discourses, argued that fears over trafficking were likewise not grounded in empirical data. Indeed, in its own primary study with 230 sex workers, and drawing on secondary data collection from non-profit organizations, GAATW (2011) found that sex workers experienced a decrease in business during the Olympic and Paralympic Games, contradicting the widespread media reporting that suggested demand for sex would explode and thereby fuel human trafficking (Vancouver Sun, 2007; Keilholz, 2008; Smith, 2010; Wallace, 2010). As with other large-scale sporting events, however, the fear generated by anti-trafficking campaigns led to an increase in surveillance and harassment of sex workers in Vancouver, validating pre-emptive spending on stringent security measures that increased the precarity of these workers. Even the police, who had earlier fuelled the panic, distanced themselves from more extreme claims. An RCMP officer, for example, stated: "while there may be an increase in prostitution, there hasn't been any link between human trafficking and prostitution" (GAATW, 2011, p. 18). A Vancouver police inspector echoed this sentiment, suggesting, "[i]t costs a lot of money to move people around. It's a short-term event, so from a trafficker's perspective, it wouldn't make a lot of sense" (GAATW, 2011, p. 18).

The speculative nature of claims over the scope of "slavery" and human trafficking runs through most anti-trafficking campaigning. For instance, in the National Action Plan to Combat Human Trafficking, Public Safety Canada (2012) contends that "[a]t any given time, it is believed that worldwide at least 2.45 million people are forced to perform degrading, dehumanizing and dangerous work in conditions akin to slavery" (p. 4). The Polaris Project (n.d.) reports a vastly larger estimate of at least 27 million people in modern-day slavery across the world, as does NASHI (2013). Trafficking numbers are similarly vague. For example, two of the NGOs examined here claim only that "[h]uman trafficking is far more prevalent in B.C. than many believe" (Surrey Women's Centre, 2013, para. 2) and that "[h]ere in Canada, as you will come to realize, we do have human trafficking occurring in large numbers all across the country" (Canadian Crime Stoppers Association, 2013a, para. 1). When numbers are given, estimates of trafficking victims coming into Canada range anywhere from 800 to thousands per year; worldwide estimates range anywhere from 800,000 to four million or more per year (Macklin, 2003; McDonald \& Timoshkina, 2004; Oxman-Martinez, Lacroix \& Hanley, 2005). Despite the claims of the prevalence of trafficking and the resources that have been poured into 
policing, criminal charges are relatively rare, suggesting that the numbers may be less certain than is often claimed. According to the National Action Plan, between 2005 and 2012, twenty-five convictions of human trafficking specific offences were secured in Canada, while approximately fifty-six additional cases were before the courts at the time that the report was released (Public Safety Canada, 2012). By April 2013, forty-three of 132 cases of domestic human trafficking for sexual exploitation were completed, with thirteen convictions handed down for human trafficking specific offences and the remainder for human trafficking related offences (RCMP, 2013). It is notable that over ninety percent of convicted and pending cases of human trafficking in Canada comprise domestic human trafficking, with a majority involving human trafficking related, and not specific, offences, such as procuring, assault, sexual assault, kidnapping, keeping common bawdy-house, uttering threats, extortion, and conspiracy (Public Safety Canada, 2012; RCMP, 2013; Roots \& De Shalit, 2014). Moreover, since 2002, only three charges have been laid under Section 118 of the IRPA, with no convictions to date (Public Safety Canada, 2012; Roots \& De Shalit, 2014).

Some scholars argue that estimating the number of trafficking victims is "intrinsically unverifiable" (Weitzer, 2012, p. 1369). The Canadian Council for Refugees (2013a), the only NGO receiving federal dollars for anti-trafficking programming that offers substantive critical perspectives on trafficking, argues that statistics in this area are difficult to verify for a number of reasons:

Estimates of the number of trafficked persons vary widely. The variation can be explained partly by the fact that, since trafficking involves numerous illegal activities, there are no official statistics available. However, the variation is also the consequence of widely differing interpretations of what it means to be trafficked. (para. 8)

This last point is crucial, as it highlights the importance of the language and representations used to frame trafficking. As we argue below, by configuring trafficking as a form of slavery, by demonizing the trafficker, and especially by conflating trafficking with prostitution and women with children, organizations produce a sense of crisis and of a vast and growing problem. The corresponding media coverage is plagued by an exaggerated focus on the sex trafficking of women and children, despite the Trafficking Protocol's reference to all forms of labour as potential sites of trafficking (Cheng, 2008; Public Safety Canada, 2012). It is for this reason that an examination of the discourses of trafficking is so important. Before turning to that discussion, however, we will briefly consider the funding contexts within which media strategies take place.

\section{Show me the money: Anti-trafficking legislation, policy, and NGO funding}

In 2005, the anti-prostitution organization Coalition Against Trafficking in Women (CATW) launched a call to the public to follow the human trafficking money trail. The then co-executive director, Dorchen Leidholdt, suggested that "buyers of sex" at a local level fuel the purchase of sex on a global scale, inevitably leading to the sexual slavery of women and children (CATW-International, 2005). CATW's understanding of trafficking reflects the dominant narrative in linking trafficking directly with sex work 
and takes an explicitly anti-prostitution position that calls for the eradication of the sex trade and punishment for the "buyer" rather than the "bought." While we vehemently disagree with CATW's logic, the organization's call to follow the money is useful. However, we contend, it is the flow of government money that is especially important to follow. The relationships between funders and NGOs is complex, with organizations constantly working to negotiate what are potentially fraught conditions imposed by funding requirements. What a number of studies have found, however, is that state funding often serves to co-opt NGOs, and shapes their work and political positions by directing funding at certain types of projects and not others, leaving them with limited ties to grassroots organizing and the communities they serve (Yadama, 1997; Jalali, 2013). While it is difficult to establish with any certainty the degree to which federal funding has shaped the approaches taken by individual organizations, our study does demonstrate significant congruence between federal and NGO positions.

In the current Canadian context, it is especially important to examine the relationships between the government and NGOs because the federal Conservative government under Prime Minister Stephen Harper has implemented a highly centralized and controlled approach to information management and its funding practices in a host of areas. The cancellation of the long-form census has received much public attention (Darroch \& Darroch, 2010), as have restrictions placed on government scientists speaking about issues like the tar sands or fisheries that diverge from the justification of an extractive economic model (Nelson, 2013). The government has paid much more attention to "branding" exercises, for example in reframing Canada's military and national identity in terms of combat rather than peacekeeping (McKay \& Swift, 2012). Crucially, these attempts at information management extend beyond the state apparatus itself, with government funding (or cuts to funding) used to sustain supportive voices or to undermine critical voices in a host of areas. Foreign aid organizations like Kairos, for example, have been defunded due to accusations that they supported anti-Israel projects, a fate also suffered by the Canadian Arab Federation (Siddiqui, 2011). One result of this tightening of government control over information and funding has been a tendency to shift from evidence-based approaches to policy in favour of more ideologically driven policies, which is particularly evident in relation to human trafficking.

In addition to this focus on information management, the Conservative government has tended to place issues of security and policing higher on the agenda than the other major political parties (Dobrowolsky, 2008). This plays a strong role in the federal government's current interest in anti-trafficking measures. Combining securitization with a desire for a greater control over immigration, the Conservative government, with its neoliberal agenda, has been given a window of opportunity to kill two birds with one stone (Dobrowolsky, 2008). At the same time, though, the Conservative position draws on broader national and international trends. Nationally, anti-trafficking policies are presented as part of a long Canadian tradition of support for human rights, a perspective that also links it with other "humanitarian" nations (Roots \& De Shalit, 2014). Anti-trafficking initiatives developed by the UN and in other national contexts have also influenced the Conservative position, although, as noted earlier, in the im- 
plementation of the National Action Plan to Combat Human Trafficking we also see specific Canadian approaches.

In following the anti-trafficking money trail, we contacted the government departments overseeing the five funding envelopes detailed below, receiving responses with complete lists of funded initiatives from the Department of Justice and Public Safety Canada. The remainder were located through the "Proactive DisclosureDisclosure of Grant and Contribution Awards over \$25,000" notice released by Status of Women Canada and the Department of Foreign Affairs and International Trade. From these sources, we were able to compile a list of eighteen NGOs that currently receive federal funding dollars for anti-trafficking initiatives.

Funding of these NGOs reflect government priorities, but also a growing international pressure to implement anti-trafficking initiatives. Indeed, both the United Nations and the United States have voiced criticisms in the past of Canada's perceived lacklustre anti-trafficking record. The United States has condemned Canada for being an easy target for trafficking activities due to its allegedly lenient immigration practices (OxmanMartinez, Lacroix \& Hanley, 2005), despite the fact that Canada's first piece of legislation specifically targeting human trafficking, Section 118 of the IRPA, was brought into force over a decade ago in 2002 and carries a maximum sentence of life imprisonment, a \$1million fine, or both. Given that Section 118 was implemented by a federal Liberal government, we can see that while the Conservatives have taken a particularly hard line stance, support for anti-trafficking measures is quite broad. Since 2002, under both Liberals and Conservatives, government anti-trafficking initiatives have expanded significantly. This increase in state attention is most apparent in the work of the Interdepartmental Working Group on Trafficking in Persons (IWGTIP). Originally established in the 1990 s as an ad hoc committee dedicated to advancing anti-trafficking initiatives in Canada (Oxman-Martinez \& Hanley, 2004), the IWGTIP is currently jointly led by the Department of Justice and the Department of Foreign Affairs and International Trade, and consists of numerous agencies and departments, including the Canada Border Services Agency, Criminal Intelligence Service Canada, Citizenship and Immigration Canada, Human Resources and Skills Development Canada, Indian and Northern Affairs Canada, Public Safety Canada, Royal Canadian Mounted Police, and Status of Women Canada. The professed aim of the IWGTIP is to develop comprehensive strategies that target all forms of human trafficking (DFAIT, 2013).

The Conservative government's emphasis on stopping trafficking is reflected in its National Action Plan, which included an announcement that they would be replacing the IWGTIP with a newly appointed Human Trafficking Taskforce, led by Public Safety Canada (2012). Also included in the Action Plan is a stated commitment to following the "4-Pillars" approach to anti-trafficking work, as outlined in the UN's Trafficking Protocol. The 4-Pillars are identified as "the prevention of human trafficking, the protection of victims, the prosecution of offenders, and working in partnership with others both domestically and internationally" (p. 9, emphasis added). A key element of the government's plan is to enlist the support of NGOs, interest groups, and institutions through funding incentives. Five federal programs funnel this money: 1) Contribution Program to Combat Child Sexual Exploitation and Human Trafficking, 
administered by Public Safety Canada; 2) Victims Fund, administered by the Department of Justice; 3) Women's Program, administered by Status of Women Canada; 4) Anti-Crime Capacity Building Program, administered by the Department of Foreign Affairs and International Trade; and 5) Global Peace and Security Fund, also administered by the Department of Foreign Affairs and International Trade. Despite the broader neoliberal context of funding cuts and austerity measures (Ruckert \& Labonté, 2012), it is notable that the federal government has chosen to allocate significant resources, budgeting nearly $\$ 8$ million for anti-trafficking activities in the 2012/2013 fiscal period and pledging to invest over $\$ 6$ million in human trafficking activities annually (Public Safety Canada, 2012). The National Action Plan, in which this budget is outlined, comes ten years after Canada's ratification of the Trafficking Protocol, and is the first federal attempt to allocate funds toward human trafficking activities in a concerted way, both at the state and NGO levels. Many of the programs discussed in this article were funded prior to the release of the Action Plan under the five federal programs aforementioned. Since the release of the 2012 human trafficking budget, however, the government's funding approach has clearly become more purposeful. It is perhaps not surprising, then, that NGOs starved of other sources of revenue may tailor their work to satisfy these new dictates and apply for federal funding dollars.

In many cases, the NGOs funded under these programs have been engaged in various areas of work for many years, often on a variety of issues other than human trafficking, including homelessness, legal rights, Aboriginal rights, medical care, violence against women, refugee claims, temporary foreign worker policies, and more. Most of the organizations advocate for social change and deem themselves non-partisan. In fact, much of their work does not align with the Conservative government's austerity, security, and anti-immigration measures. In this regard, our picture of the federally funded NGO is complicated by competing and, at times, opposing interests. We argue, however, that the government's desire to position itself as "anti-trafficker" in the international arena, in part due to the current global momentum for support of antitrafficking measures and policies, fuels its funding approach and opens doors for organizations that are otherwise underfunded and under-resourced to expand their work into the area of anti-trafficking.

\section{A closer look: Textual and media analysis of federally funded anti- trafficking programs}

Having identified eighteen NGOs receiving federal funding, we set out to analyze their websites to determine the extent to which their communication and media interventions mirrored those of the government and of dominant conceptions of human trafficking more broadly. The websites often included a range of materials, from descriptions of the organizations themselves to images and videos for campaigns they had developed, and thus provided a valuable resource for analyzing both the perspectives of the organization and their communication and media strategies. The Canadian Crime Stoppers Association (2014), for example, is currently focusing on a campaign against human trafficking, an announcement for which takes up much of their homepage despite the fact that crime prevention more broadly is their primary 
mandate. Their trafficking page outlines where some of their government anti-trafficking money will go:

Public Safety Canada is funding the development of posters, pamphlets and presentations which will be provided to every Crime Stopper program for use in raising awareness in the communities we serve. (Canadian Crime Stoppers Association, 2013a, para. 4)

It is in this sense that federal funding has worked to extend the government's ability to promote particular narratives as "truth" without significant interruption (van Dijk, 2003; Campbell \& Gregor, 2004). Understanding these organizational dimensions is crucial to determining how meaning is codified, examined, and interpreted and thus forms a vital element in any analysis of such messages (Carrera-Fernandez, GuardiaOlmos \& Pero-Cebollero, 2013). This approach also serves to highlight the policy implications, demonstrating the extent to which anti-trafficking discourse also has very real effects in areas like stricter immigration control, enhanced surveillance of sex workers and migrants, and heightened securitization (Roots \& De Shalit, 2014). As we shall see, though, there is never a perfect congruence between government and NGO discourses, and, in some cases, funded organizations offer narratives that challenge those of the state.

A number of themes emerged as we explored the language and images used to define and describe human trafficking and trafficking victims on the various organizational websites. We engaged in a grounded, iterative coding and analysis process following Strauss and Corbin (1990), which included making note of the terms and conceptualizations that the NGOs employed. Some of the most common included references to slavery and labour exploitation, women and girls/children as victims (in particular those who are racialized), differentiations between smuggling and trafficking, immigration push and pull factors, prostitution and sexual exploitation, the trafficker as a criminal or crime group, violations of human rights, the increasing prevalence of human trafficking in Canada, and vulnerable Indigenous women. Given the overlap in many of these conceptualizations, we categorized and organized them under three rubrics or themes: (1) modern-day slavery; (2) conflations; and (3) the trafficker. In some cases, language or concepts underwrote each of the rubrics. For example, racialized and Indigenous women were routinely evoked in discussions of modern-day slavery, in conflations of prostitution and trafficking, and in discussions of the trafficker. In the following, we analyze each of these three themes in turn, paying particular attention to the use of emotive language and imagery.

\section{Modern-day slavery}

The most common way in which both the Canadian government and the NGOs under consideration engaged in anti-trafficking work frame human trafficking is as a form of slavery. This powerful narrative has its roots in the widely discredited and deeply racist white slavery panic that was prevalent in the early $2 \mathrm{O}^{\text {th }}$ century. First used to describe the enslavement of white women by racialized men, and later understood interchangeably with prostitution, the white slavery panic swiftly became the focus of moral crusaders across Europe, the Americas, and elsewhere (Doezema, 2000; 
Donovan 2006; Bernstein, 2007). Anti-white slavery efforts were said to protect "vulnerable" women from sexual exploitation and a life of prostitution. As a number of historians have emphasized, however, the panic had more to do with restricting women's mobility and access to public space, as well as the criminalization of racialized men and, in the case of Canada, "undesirable" Chinese immigrants (Sharma, 2005). In late $19^{\text {th }}$ century and early $20^{\text {th }}$ century Canada, Chinese men were depicted as "the sexual predators of White women" and targeted by anti-trafficking efforts, which coincided with a number of anti-Chinese bills (Sharma, 2005, p. 98). While white slavery has been debated for its actual existence (Bernstein, 2007; Connelly, 1980; Rosen, 1982), most accounts reject the framework of slavery for understanding these histories of migration. Despite this, related narratives continue to be found in contemporary antitrafficking discourse and are embedded in many of the policies aimed at addressing human trafficking (see, for example, the 1949 Trafficking Convention, the 2000 Trafficking Protocol, and the Victims of Trafficking and Violence Protection Act of 2000).

The language of "slavery" infuses both legislative interventions and government communications. The National Action Plan (Public Safety Canada, 2012) does not define slavery - a telling omission - but mentions it five times, with two of the references linking enslavement with forced prostitution (Public Safety Canada, 2012, pp. 27-28), one of the key conflations so often made in anti-trafficking discourses. These evocations of slavery are mirrored by the eighteen NGOs we considered, with this shared emphasis lending rhetorical and moral force to the inflated and often unsubstantiated claims about the extent of the trafficking problem that we noted earlier. Thus, the People's Law School (2010) claims that "[b]illions of dollars are made every year though the illegal exploitation of people who - through force, fraud and threats-are compelled to work in slave-like conditions" (p. 1). NASHI (2013) goes so far as to suggest that "[t]here are more slaves in the world today than ever before in history" (para. 3). Rarely, however, do these organizations attempt to concretize what slavery actually is. Their emotive language evokes "abolitionism" as a way of furthering the connection to slavery, and of reinforcing ideas of the "saviour," but in practice it effaces the material histories of racist and colonial chattel slavery.

The framing of trafficking in relation to histories of slavery is especially evident in visual evocations of slave-like conditions, although the way in which this is framed differs between organizations. For example, both the main homepage and the specific anti-trafficking page of the Canadian Crime Stoppers Association's (2013a; 2014) website depict a pyramid of heavy metal chains, suggesting the bondage of slavery. The website of NASHI (2013) features images of a man tied to a chair with ropes, and a woman peering out from behind metal bars. PACT-Ottawa's (2013a) website is simultaneously more direct and more nuanced in its understanding of trafficking. The organization puts on yearly "End Slavery Days," with a page on its site depicting the posters from each year's events, many of which feature slavery-related imagery. At the same time, PACT-Ottawa (2013c) acknowledges the variety of forms taken by "slavery," evident especially in the focus on education about labour trafficking for End Slavery Day 2011, an approach that moves away from the more common focus on sex work. For that event, fair trade companies were heavily involved, thus moving away from 
the law and order perspective favoured by the government and some other organizations and towards a consumerist solution, with supporters asked to "fight slavery one purchase at a time" (PACT-Ottawa, 2013c, n.p.).

The posters for End Slavery Days 2009 and 2012 focus on slavery and bondage much more explicitly, both offering profoundly ambivalent images that allow for multiple interpretations. The 2009 poster image, for example, depicts the hands of what appears to be a white woman shackled by handcuffs (PACT-Ottawa, 2013b). Bondage is thus the focus of the image, but it is unclear who is being bound and to what end. Are these the hands of a trafficked woman, the poster inviting us to break her bonds? Or, are they the hands of the passive bystander who refuses to help, a reading suggested by racially coding the hands as white, the colour of the saviour in anti-trafficking discourses? While both readings are possible, the overriding theme is bondage, as if this simple fact by itself should drive us into action. Reading the image against the grain, however, opens up another option. The hands are held not by chains but by handcuffs, the restraint of choice for law enforcement. Thus, presumably unintentionally, the image can evoke an interpretation that highlights the extent to which anti-trafficking initiatives all too often end up criminalizing the ostensible victims, a tendency especially strong in relation to sex workers.

The 2012 poster is similarly ambivalent and is again driven by racialized imagery. The theme of this End Slavery Day was "Speak Out: Youth Against Slavery," with the accompanying photo depicting the face of a white woman staring straight at the viewer, but with her mouth covered by what appears to be a darker-skinned male hand (PACTOttawa, 2013b). As with the 2009 poster, we can read the woman in the image either as a trafficking victim or as one of those who need to "speak out," the hand over her mouth connoting a dangerous silence. The racial coding of the woman as white allows for either reading. The man's hand in the image is not dramatically darker than the woman's face, but it is dark enough to introduce a sense of danger and violence imputed to racialized masculinity. Insofar as we read the hand as that of the trafficker, the image feeds into racialized and gendered stereotypes that we discuss at greater length below.

There are a number of obvious problems associated with defining trafficking in terms of slavery. As with the white slavery panics of a century ago, these narratives serve to reverse the racial dynamics of exploitation. European slavery was premised on an ideology of white supremacy, but anti-trafficking discourses tend to implicitly or explicitly racialize the perpetrators of trafficking, thus displacing the source of exploitation onto a racialized "other." In so doing, the exploitative labour relations characteristic of neoliberal capitalism are erased as well (Bernstein, 2007; Anderson \& Andrijasevic, 2008). Thus, for example, Canadian state programs, such as the Live-in Caregiver or Temporary Foreign Worker programs, that produce contexts in which exploitation of often racialized migrants can flourish (Walia, 2010), are absolved by antitrafficking language, the state becoming instead the saviour of the trafficked. Critical scholars have therefore asked, "How [do we] draw a line in the sand between 'trafficked' and 'not trafficked but just-the-regular-kind-of exploitation' migrants?" (Anderson \& Andrijasevic, 2008, p. 141). These critics argue that conceptions of free and forced 
labour should not be posed as binaries, but must be regarded as context-specific constructions under global patriarchal capitalism (Anderson \& Andrijasevic, 2008). To reify human trafficking as "modern-day slavery" without taking this continuum of exploitation into consideration, and without exploring the ways in which contracts, labour laws, and related policies have changed over time, serves simultaneously to reinforce racialized and gendered conceptions of labour and migration, and to render invisible a wide range of other spaces in which workers and migrants are exploited.

\section{Conflations}

In addition to advancing a modern-day slavery framework, the NGOs under review consistently conflate different categories, most notably women with children, and trafficking with sex work. An example of the first conflation is provided by the Cape Breton Inter-Agency on Family Violence, which received funding for a project on women's issues, but extended this to focus on the "victimization of women and children by society" (McNeil, 2009, para. 1). Again, definitional clarity is lacking, as there is no attempt to define children or to acknowledge at what age one is a child versus a youth versus an adult. In conflating women with children, NGOs suggest that they experience trafficking or labour migration similarly, thus infantilizing women and perpetuating paternalistic, preventative, and reactionary responses that propel the notion that women, like children, must be precluded from making "unsound" decisions. As the Canadian Council for Refugees (CCR) (2013C) contends, "[trafficking] exploits the vulnerable. This is why women and children are often the victims" (para. 3). As saviour, the NGO takes on a paternal role. Not only is agency denied to women, but also to children and youth, who are likewise deemed incapable of engaging meaningfully with matters that affect their lives, a tendency that runs through much of contemporary culture (for critical analyses, see O'Connell Davidson, 2005, 2011; Sircar, 2011; JJ, 2013).

This process of gendered infantilization intersects in Canada with the frequent conflation of Indigenous people with children in the news media. Harding (2006), for example, traces the ways in which Indigenous people in British Columbia have historically been depicted as inferior adults or as children in comparison with white colonizers. Historically, they were seen as lacking in discipline and decision-making capabilities, a view that justified the creation of residential schools, theft of property, and denial of rights (Harding, 2006), as well as forced sterilization (Black, 2012). The dynamic of the white man and the state as benevolent guardian and saviour of the "feeble" and dependent Indigenous inhabitant is maintained today (Harding, 2006; Jiwani \& Young, 2006). The representation of the benevolent state is, therefore, deeply rooted in the history of colonization. In the case of human trafficking, then, Indigenous and racialized women are subjected especially strongly to rescue missions devoted to saving them from themselves, and from the men of their communities. These approaches are reflective of paternalistic risk management and national security measures rather than the rights, needs, or agency of "victims" (Aradau, 2003; Harding, 2006; Jiwani \& Young, 2006).

The conflation of women and children is exacerbated by the even more common conflation of trafficking with sex work. Indeed, while many organizations gesture to- 
wards other forms of trafficking, it is primarily sex trafficking that has gained public attention. This has produced coalitions of often unlikely allies, such as in the United States, where Hillary Clinton's campaign to end human trafficking was heavily influenced by Christian and conservative lobbyists, as well as by anti-prostitution feminist lawyers (Soderlund, 2005). In Canada, federal funding has likewise gone to a diverse range of organizations. Christian influence can be seen in Project 417 (2013), a selfidentified holistic ministry helping vulnerable people, whose website stresses that trafficking victims are "exploited as sex workers every day in Toronto and across Canada" (What is Human Trafficking? video, slide 4). The Women's Support Network of York Region (2013) similarly argues that "victims of trafficking [are] exploited for commercial sex or labour purposes," a claim that separates sex from labour on the one hand (a perspective rejected by most sex workers and allies), while still conflating them on the other. As we saw earlier, PACT-Ottawa (2013a) offers a much greater awareness of the complexities of these issues, stressing that, "cognizant of the links between sex work and human trafficking, PACT-Ottawa resists conflating these issues. PACTOttawa recognizes the complex and controversial nature of sex work" (para. 3). Thus, the organization claims to keep the two apart, even while returning to the position that "as an anti-trafficking NGO, the vision of PACT-Ottawa is to recognize the dignity and promote the well-being of all trafficked persons, some of whom may be exploited in coerced sex work" (PACT-Ottawa, 2013a, para. 3). The poster for PACT-Ottawa's (2013b) End Slavery Day 2010, which featured a talk by the RCMP, reinforces this view, presenting a blurry photograph of what appears to be the silhouette of larger male figure looming over a smaller woman or girl, strongly suggesting sexual exploitation of children, youth, and/or vulnerable sex workers.

Such approaches tend to perpetuate the victimization discourse described earlier, thus enabling the state or the NGO to claim the right to intervene. As O'Connell Davidson (2011) suggests:

Stressing the link between 'child trafficking' and the sex industry operates to underscore the profoundly damaging consequences of 'trafficking' and to unequivocally construct those involved as either victims or villains. (p. 459)

The involvement of children and youth in the sex trade is considered exploitation irrespective of the circumstances involved (O'Connell Davidson, 2011), a position that is then often extended to women as well. Due to the illicit and criminalized nature of prostitution, some find it difficult to imagine that an adult woman, let alone a youth, would choose a life of sex work for herself. Without agency, the "subject" becomes a victim of circumstance and an object of intervention (Agustín, 2003; Arthurs, 2012).

In the Canadian context, the conflation of trafficking and sex work has led to increased attention being placed on "domestic" victims of trafficking and, in particular, on Indigenous girls and young women. This goes against the UN framework that understands trafficking in relation to borders. The result has been a dramatic expansion of the numbers of those deemed trafficked, and a much greater emphasis placed on policing as a response. Significantly, it is also in this context that we can see the deeply racialized nature of anti-trafficking discourses, with "local" Indigenous women joining 
racialized "foreign" women as objects of concern. Such constructions of trafficking and victimization are explicit in the National Action Plan's pledge to

raise awareness about trafficking that focuses on prevention, and provide culturally and historically informed training to enforcement officials on the circumstances that may contribute to human trafficking within Aboriginal communities. (Public Safety Canada, 2012, p. 12)

As with the language of slavery, here again we can see the extent to which antitrafficking discourses can efface histories of exploitation, in particular by locating the problem within Indigenous communities, as well as the ways in which processes of visibility and invisibility overlay trafficking narratives. Indeed, Indigenous women have been made hypervisible through their configuration as both criminals, a situation reflected in their dramatic overrepresentation in prisons, and as victims. Both approaches have produced increased control and discipline of Indigenous women and their communities, in particular through enhanced policing (England, 2004; Jiwani \& Young, 2006). Yet, these same representations have rendered Indigenous women invisible, by conveniently omitting histories of colonialism and silencing their voices in the media and elsewhere (England, 2004; Hunt, 2014). Thus, as England (2004) suggests, these twinned processes of hypervisibility and invisibility reinforce a policing perspective focused on the control of space, denying agency to Indigenous women in particular.

Indigenous scholars like Sarah Hunt $(2010,2013,2014)$ argue that the legal category of human trafficking itself begets legal remedies, which have in turn been primary sources of violence against Indigenous peoples and communities. In particular, sexual violence against Indigenous women, a by-product of colonialism, received little attention from the government until the concept of "human trafficking" replaced concepts of "youth sexual exploitation, intergenerational violence, and disappearance or abduction" (Hunt, 2010, p. 27). Hunt (2010) further contends that figures of Indigenous trafficking victims are unfounded and are often magnified due to the conflation of trafficking and consensual sex work. The quest to end the domestic trafficking of Indigenous women and girls has resulted in rescue-driven approaches that perpetuate imbalanced power relations between white "rescuers" and otherwise "helpless" Indigenous victims (Hunt, 2013). Instead, Hunt (2010) argues, "trafficking must be addressed as part of a legacy of sexualised violence rather than a new issue arising from contemporary social problems" (p. 30). It is this colonial legacy that is replicated rather than challenged in narratives of victims and (white) saviours.

The conflation of sex work and human trafficking also frequently depicts racialized or impoverished sex workers as "injured bodies" in need of rescue (Doezema, 2001). This has resulted in immigration policy constraints and restrictions under the guise of protecting vulnerable women from traffickers and environments in which the risk of trafficking can be exacerbated. The federal government's interventionist impulses to rescue racialized people (primarily women) from traffickers and dominant conceptions of "unfree" labour are clearly supported in the Canadian Crime Stoppers Association (2013a, 2013b) "Blue Blindfold" campaign, which features a video of predominantly white people wearing blindfolds in the presence of a white exotic dancer, a racialized server at a private home, a racialized restaurant dishwasher, and the en- 
trance to a massage parlour. More directly than the PACT-Ottawa (2013b, 2013c) posters analyzed earlier, the Crime Stoppers campaign, which is cited as a key intervention in the National Action Plan (Public Safety Canada, 2012), sets up the white viewer as the potential saviour. It asks the public to open their eyes to instances of human trafficking in Canada to support the eradication of "this illegal activity" (Canadian Crime Stoppers Association, 2013b, n.p.). Ironically, those blindfolded are receiving services from the allegedly trafficked workers, a reality that goes unremarked in the video. Here we see clearly how labour is effaced as the locus of exploitation, displaced instead onto the act of trafficking and its implied "other" perpetrator.

The trafficker

It is to the perpetrator that we now turn. As our analysis thus far has shown, depictions of people deemed to have been trafficked pose them primarily as feminized, racialized, and infantilized victims requiring rescue. Approaches that identify violence as a problem between an individual victim and an individual perpetrator naturalize and institutionalize particular people and groups as "risk-bearing" rather than "rightsbearing," thereby contributing to state responses that are focused on security measures, and risk assessment and management (Amar, 2009; Aradau, 2003). Gendered and racialized anti-trafficking crusades tend to treat all women, but Indigenous and immigrant women in particular, as naturally at-risk of engaging in acts that pose threats to themselves and to society (Aradau, 2003; Doezema, 2001; Harding, 2006; Jiwani \& Young, 2006). Rather than a product of social conditions such as poverty, racism, or misogyny, risk becomes an ontological characteristic of these women themselves, attached to their gender, and of their racialized "home" context (Arthurs, 2012; Jiwani \& Young, 2006).

As we have seen, some anti-trafficking NGOs offer a more nuanced understanding of these social contexts than does the government. However, because the narrative and imagery of trafficking fixes in place an understanding of the process of victimization, they rarely if ever apply such nuance to the trafficker and the practice of trafficking itself. The individualization of trafficking sets up a stark narrative of good and evil in which it becomes difficult to see the trafficker as anything other than male, as somehow "foreign" to Canada, be it through birth/residence in another country or through non-white skin, and as irredeemably evil. The trafficker and the rescuing NGO or government are thus presented as being in a contest over who will ultimately influence and control the fate of the passive trafficked victim. This is evident in many website images exhorting us to speak for the victim. Depictions of this masculine, criminalized violence as the source of trafficking acts as a mechanism of narrative closure, leading policy in what becomes only one possible direction: a security and policing approach in which the state plays a central role. It is for this reason that a critical engagement with the image and the complex realities of the trafficker and trafficking is so crucial.

The gendered nature of trafficking is especially evident in the distinction drawn by many of the NGOs between smuggling and trafficking, with their arguments replicating government legislation and narratives in this respect. The People's Law School (2010), the CCR (2013a), and PACT-Ottawa (2013a), for example, distinguish between 
trafficking as forced and exploitative migration, and smuggling as voluntary and assisted illegal border crossing. The CCR (2013a) notes:

It is useful to distinguish between trafficking in persons and people smuggling. A person who is trafficked is kept under the control of the traffickers, whereas a migrant smuggler simply facilitates clandestine entry into a country. (para. 2)

This distinction runs along gendered lines, with trafficking most often seen as happening to a feminized victim, and smuggling to masculinized and agentic subjects of crime (Ditmore, 2005; van Liempt, 2011). As van Liempt (2011) argues, "[m]en are more often depicted as in control and women as dependent/docile when assisted types of migration are discussed" (p. 181). Legislation builds on this gendered distinction between human trafficking and human smuggling, erasing in the process the broader contexts of migration, and failing to account for the role of the state itself in creating environments in which "assisted" migration becomes necessary (van Liempt, 2011).

A number of the stated positions of the federally funded NGOs align with the federal government's notion that human trafficking is a criminal act performed by a trafficker who is part of an organized crime group or an experienced individual criminal, most often seeking to bring women across Canadian borders illegally, for illegal purposes, or under false pretences (Department of Justice, 2013). Criminalizing the trafficker in this way may seem self-evident, but in fact needs to be interrogated. To begin, "organized crime groups" and "criminal organizations" are often defined in legal terms as networks of three or more people who work together to benefit from the commission of a serious crime (see, for example, the Canadian Criminal Code section 467.1 (1), or the UN Convention on Transnational Organized Crime, Article 2). As Thai sex worker rights organization, Empower Foundation (2012), notes, in practice this means that "a manager, cashier and motorcycle transport boy can be labelled as an organized crime gang" (p. 44).

With this in mind, we would need to be careful about taking at face value NASHI's (2013) claim that "[human trafficking] is the fastest growing organized crime activity in the world today" (para. 3). Further, the ways in which NGOs characterize trafficking build on the gendered narratives that we have already examined. Thus, the People's Law School (2010) states:

Human traffickers keep their victims hidden, trapped, frightened, and silent by using various methods of control, like lying to them, threatening violence to them or their families, or withholding their identification papers. (p. 1)

This dichotomized relationship renders the victim entirely passive and at-risk. The People's Law School (2010) goes on to suggest that "[t]raffickers prey upon people's vulnerability by offering false promises of a better job, more money, and a better home, or by using threats or force" (p. 5). Here we see another potentially dangerous conflation in which promises of a better life, the staple of any decent marketing campaign, are equated with threats of force in the context of migration.

Constructing the trafficker and trafficking as criminal transforms social issues of labour, global inequality, and migration into problems of border security, immigration 
control, and policing (Crépeau \& Nakache, 2006; Macklin, 2003; Wijers \& van Doorninck, 2002; Zhang, 2009). For example, the Criminal Intelligence Services Canada (CISC, 2008) maintains that human trafficking in Canada is being conducted by criminal networks that have expertise in the recruitment, transportation, and coercion of women, with the sex trade highlighted as a particular area of concern. While ostensibly designed to protect them, surveillance and policing of migrant women (under suspicion that they are entering a country illegally) are then intensified at the expense of their abilities to move freely and find work (Zhang, 2009). Movement itself is seen as the site of exploitation rather than the conditions in which labour takes place. Furthermore, the exclusive focus on individual suffering negates the need to examine ruling relations and practices (Aradau, 2003; Campbell \& Gregor, 2004). In this respect, the CCR (2013a) offers a rare and strong critical perspective, arguing:

An approach focusing on punitive measures against traffickers leaves aside the role other parties play in the violations of migrants' rights. This includes the role of the state and its officials in restricting women's movement across borders through restrictive and discriminatory immigration policies and the role of employers and those who accept the discrimination faced by migrants. (para. 16)

A number of scholars and activists paint a rather different picture to that of passive women victimized by organized crime in foreign or domestic lands. It is not uncommon, they argue, for third parties or family members to facilitate irregular migration (Agustín, 2003; Andrijasevic, 2007), and for sex workers to say that the alleged traffickers played various supporting roles in arranging their migration and subsequent work (Empower Foundation, 2012). Indeed, the movement of people across borders to so-called destination countries is dependent on a host of elements, such as insider knowledge of the documentation required to cross borders, people who are able to create believable migration documents, and others who can facilitate connections with possible employers abroad and provide financial support in the interim (Agustín, 2003; Empower Foundation, 2012). In their study of Mexican women who were defined as trafficked into the United States, eventually arriving in New York City, Ditmore, Maternick, and Zapert (2012) note that sixty-nine percent of the women interviewed knew the person who assisted their migration through a friend, a family member, or a neighbour, thus indicating a more complex relationship between "victims" and "traffickers" than many anti-trafficking NGOs account for. These findings stand in opposition to the framing of the problem by the government and NGOs, suggesting in the process that we need to carefully rethink the concept of "trafficking" itself.

\section{Beyond the hype: Counter-narratives and other NGOs}

As we have noted in a number of instances, the perspectives offered by the NGOs reviewed here tend strongly to support hegemonic and state conceptions of human trafficking, but they are by no means homogenous. In line with Jessop's (1990) conception of the state as a condensation of complex social relations, we can see the ways in which various groups have come together to produce a provisional and unstable, yet still powerful, consensus around human trafficking. These groups range 
from Christian activists to anti-sex work feminists, and include groups like PACTOttawa that offers a somewhat more nuanced view of migration. The one federally funded NGO that diverges most strongly from the dominant line is the CCR, which presents explicit counter-narratives to state definitions of human trafficking and trafficking victims, even while their approach remains within the broad contours of trafficking discourses. Thus, the CCR website acknowledges disagreements over the nature of sex work:

Some groups consider any form of prostitution to be by definition exploitative, with the result that they consider large numbers of women to be trafficked. Others reject such an approach on the basis that it denies the limited agency available to migrant (and other) sex workers and assumes that other forms of labour exploitation are less abhorrent to women. There is often a lot of focus on sexual exploitation in discussions of trafficking, but trafficking might also include such things as sweatshop labour, domestic labour or selling drugs, work in restaurants, farms, or factories, etc. (CCR, 2013a, para. 4)

Beyond this acknowledgement of the complexity of trafficking, the CCR (2013b) also discusses the impacts of state policies on those identified as trafficking victims, taking an at times highly critical stance towards the federal government. This is especially evident in their criticisms of the recent Safe Streets and Communities Act (Bill C-10), also referred to as the omnibus crime bill, which introduced amendments to the IRPA that gave immigration officials the power to deny a work permit to an international applicant out of concern that he/she might be exploited after arriving in Canada. The CCR (2013b) argues that such approaches are paternalistic and potentially harmful, stressing that states can play an important role in exacerbating the problems of migration:

Efforts by governments to restrict migration prevent most of the world (and especially women) from migrating legally... abuse and exploitation is ... shaped not just by those people labelled as 'traffickers' but also by governments, employers and those within 'receiving' countries who accept discrimination against people on the basis of their nationality and immigration status. (para. 10)

These counter-narratives are rarely acknowledged on the websites of other NGOs that receive government funding for anti-trafficking programming.

NGOs fighting for sex workers' rights, migrant justice, and labour rights, or those expressing "marginalize(d) alternative interpretations and strategies" (Jessop, 1990, p. 246), tend to avoid the language of trafficking and the evocations of modern-day slavery altogether, focusing instead on complex labour processes in which "victims" can also be agents. Many such groups do not apply for federal funding, in part because doing so would force them to adopt the language and frameworks of anti-trafficking, and might restrict the kinds of critical work they are doing. For example, No One Is Illegal-Toronto (NOII-Toronto, 2013) and Justicia for Migrant Workers (J4MW, 2013) use resilient language on their websites to describe their activities and the people they work with rather than that of victimization. J4MW (2013) focuses on breaking away 
from indentureship created by the state, as one of its video files suggests, and places emphasis on the rights and agency of migrant workers, while NOII-Toronto (2013) challenges state policies that render individuals as non-status, non-citizens, aliens, or illegals. Rather than focusing on "rescuers," as is so often the case with NGOs that urge people to take off their blindfolds, the NOII-Toronto (2013) website depicts images of rallies filled with migrants themselves and their allies. In part due to limited funding, and in part due to perspectives that clash with dominant media narratives, these groups tend to receive less positive popular attention.

Sex workers' rights organizations, such as Stepping Stone in Halifax, Stella in Montreal, POWER in Ottawa, Maggie's and the Sex Professionals of Canada (SPOC) in Toronto, Big Susie's in Hamilton, and FIRST and PACE in Vancouver, among many others, are concerned with the human rights of sex workers, both local and migrant. Instead of the dominant view of sex work as inherently coerced, however, these organizations begin from an understanding that sex workers have the ability to make informed decisions about their lives, mobility, and work, including in situations of social, legal, and economic constraint, and their websites depict rallies and protests made up of sex workers and allies (Maggie's, 2013; SPOC, 2013). Such organizations emphasize labour rights and protections rather than escape, rescue, or the punishment of "buyers." As SPOC's (2013) website maintains, "Sex workers deserve genuine labour rights, with industry-wide standards defined by sex workers themselves" (Mission \& Principles section, para. 3). Similarly, Stella (2013) and Maggie's (2013) emphasize the right of sex workers to live with dignity and respect. Led by sex workers themselves, these organizations are acutely aware of the negative political and legal ramifications associated with sex work, but they see these as the result of the larger social and legal context that enables violence and exploitation. As such, they call for the decriminalization of sex work so that workers "can control [their] own lives and destinies" (Maggie's, 2013, para. 1). Such an approach is entirely precluded within a trafficking framework that sees sex work as inherently violent and workers as passive victims.

\section{Conclusion}

Discourses of human trafficking conjure up a series of powerful images, associations, and narratives. The story of victimization and rescue plays on deep-seated gendered and racialized conceptions of global relations, and provides a media-friendly framework focused on individual responsibility and redemption, as well as a benevolent state. These media representations do not appear spontaneously, but are driven by organized campaigns in which the federal government plays a facilitating role. In the Canadian context, federal funding dollars have gone almost exclusively to groups whose narratives of trafficking match those of the government itself. In turn, the government relies on the work of these groups to buttress its own policy innovations. For example, a 2010 report on measuring the scope of trafficking financed by Public Safety and Emergency Preparedness Canada turned to anti-trafficking and anti-sex work NGOs as community stakeholders, including several of the eighteen NGOs we have looked at here (Ogrodnik, 2010). Similarly, the key priorities of ACT Alberta (2013), a funded umbrella group that includes the RCMP, directly follows the 4-Pillars outlined 
by the UN's Trafficking Protocol and the federal National Action Plan (Public Safety Canada, 2012). The result of this kind of tight relationship between the government and NGOs is a reinforcement of inflated and misleading statistics, vague definitions of trafficking, harmful media images, and potentially dangerous policy.

As a number of scholars have argued, the language of "trafficking" itself defines specific populations as victims, and is generally unhelpful in understanding the nature of migration and of the forms of exploitation and abuse through which it may take place. The consequence is a narrative of rescue in which the purported victim is rendered passive, available for saving. Critical NGOs and scholars, however, have stressed the dangers inherent in this approach. We can see these dangers clearly if we read a Crime Stoppers Q\&A brochure on human trafficking with a critical eye. Funded by Public Safety Canada through the programs discussed here, the brochure asks and answers the questions: "How can you recognize a victim?" and "What is the victim's mind-set?" The trafficking victim is clearly set up as "foreign," as the brochure suggests that they can "speak neither English nor French, or may not speak on their own behalf" (Canadian Crime Stoppers Association, 2013a, p. 2). We are warned that if someone speaks for them, we should be suspicious, as the victim may "be frequently accompanied by an individual who may be their trafficker" (Canadian Crime Stoppers Association, 2013a, p. 2). Family members, friends, or other associates are thus all framed as potential traffickers, and thus under threat of criminalization. Especially telling, however, are the answers to the second question, the victim's purported mindset. The first three points state that they may "[n]ot self-identify as victims of human trafficking"; they may "[b]e taught to distrust outsiders, especially law enforcement ... Foreign victims may be afraid they will be detained and deported"; and finally, they may "[f]eel better in their current situation than where they cam [sic] from, even if they are being exploited" (Canadian Crime Stoppers Association, 2013a, p. 2). The message here could not be clearer. Not only do the victims have no agency, but we should also actively disbelieve anything that they may say about their own life circumstances or relationships. Most tellingly, fears they may express about law enforcement or border services are not only misplaced, but in fact a further sign of their trafficked status and victimized mind-set; thus, the state can only be a saviour.

Our examination of the websites of NGOs that receive federal dollars for anti-trafficking initiatives found that they both draw on and reinforce dominant narratives. In this context, counter-narratives produced by non-federally funded NGOs are significant in that they have more room to problematize the dominant human trafficking story and critique ingrained knowledge. These organizations challenge the simple dichotomization of "victims" and "criminals" and argue that systemic oppression and violence rather than simply individualized relationships of control are the major danger facing migrants. In this respect, they also look especially at how state practices themselves produce or exacerbate the conditions enabling these dangers. It is vital that these NGOs have a voice within national and international arenas so that alternative ways of thinking about human trafficking, immigration policy, migrant labour, and sex work are at the forefront. Yet, as this artcile has shown, government funding policies and communication strategies actively hinder these possibilities. 


\section{Websites}

Criminal Code of Canada, http://laws-lois.justice.gc.ca/eng/acts/C-46/

Department of Foreign Affairs and International Trade, http://www.international.gc.ca/international/index.aspx

Department of Justice Canada, http://www.justice.gc.ca/eng/

Global Alliance Against Trafficking in Women, http://www.gaatw.org/

Immigration and Refugee Protection Act, http://laws.justice.gc.ca/eng/acts/i-2.5/

Maggie's: Toronto Sex Workers Action Project, http://maggiestoronto.ca/about

National Action Plan to Combat Human Trafficking, http://www.publicsafety.gc.ca/cnt/rsrcs /pblctns/ntnl-ctn-pln-cmbt/index-eng.aspx

Protocol to Prevent, Suppress and Punish Human Trafficking, Especially Women and Children, Supplementing the United Nations Convention against Transnational Organized Crime, http://www.osce.org/odihr/19223

Project 417, http://project417.com/project417

Public Safety Canada, http://www.publicsafety.gc.ca/index-eng.aspx

Safe Streets and Communities Act (Bill C-10), http://laws-lois.justice.gc.ca/eng/annualstatutes /2012_1/

Status of Women Canada, http://www.swc-cfc.gc.ca/index-eng.html

UN Convention on Transnational Organized Crime, http://www.unodc.org/unodc/treaties/CTOC/

Victims of Trafficking and Violence Protection Act of 2000, http://www.state.gov/j/tip/laws /61124.htm

Women's Support Network of York Region, http://www.womenssupportnetwork.ca/Definition.htm

\section{References}

ACT Alberta. (2013). Mission and philosophy. URL: http://www.actalberta.org/about-act.php?sid =70 [June 18, 2013].

Agustín, Laura. (2003). Sex, gender and migrations: Facing up to ambiguous realities. Surroundings, 23(1), 84-98.

Agustín, Laura M. (2007). Sex at the margins: Migration, labour markets and the rescue industry. New York, NY: Zed Books.

Amar, Paul. (2009). Operation princess in Rio de Janeiro: Policing 'sex trafficking,' strengthening worker citizenship, and the urban geopolitics of security in Brazil. Security Dialogue, 40(4-5), 513-541.

Anderson, Bridget, \& Andrijasevic, Rutvica. (2008). Sex, slaves and citizens: The politics of anti-trafficking. Soundings, 40 (Winter), 135-145.

Andrijasevic, Rutvica. (2007). Beautiful dead bodies: Gender, migration and representation in antitrafficking campaigns. Feminist Review, 86, 24-44.

Aradau, Claudia. (2003). Trafficking in women: Human rights or human risks? Canadian Woman Studies, 22(3-4), 55-59.

Arthurs, Jane. (2012). Distant suffering, proper distance: Cosmopolitan ethics in the film portrayal of trafficked women. International Journal of Media \& Cultural Politics, 8(2\&3), 141-158.

Black, Edwin. (2012). War against the weak: Eugenics and America's campaign to create a master race, ( $2^{\text {nd }}$ edition). Washington, DC: Dialog Press.

Bernstein, Elizabeth. (2007). The sexual politics of the "new abolitionism." Differences: A Journal of Feminist Cultural Studies, 18(3), 128-151.

Bloch, Alexia. (2003). Victims of trafficking or entrepreneurial women? Narratives of post-Soviet entertainers in Turkey. Canadian Woman Studies, 22(3\&4), 152-158.

Campbell, Marie Louise, \& Gregor, Frances Mary. (2004). Theory "in" everyday life. In W. K. Carroll (Ed.), Critical strategies for social research (pp.170-180). Toronto, ON: Canadian Scholars' Press.

Canadian Council for Refugees (CCR). (2013a). Understanding trafficking globally and locally. URL: http://ccrweb.ca/en/trafficking-globally-locally [June 18, 2013].

Canadian Council for Refugees (CCR). (2013b). Comments—Bill C-10: Trafficking. URL: http://ccrweb.ca/en/comments-bill-c1o-trafficking [June 18, 2013]. 
Canadian Council for Refugees (CCR). (2013c). About trafficking-Canada and abroad. URL: http://ccrweb.ca/en/about-trafficking [August 24, 2013].

Canadian Crime Stoppers Association. (2013a). Human trafficking. URL: http://www.canadian crimestoppers.org/programs/humantrafficking [June 19, 2013].

Canadian Crime Stoppers Association. (2013b). Blue blindfolds. [Video] URL: http://www.canadian crimestoppers.org/media/HT_COPY.mov [June 29, 2013].

Canadian Crime Stoppers Association. (2014). Homepage. URL: http://www.canadiancrimestoppers .org/home [June 11, 2014].

Carrera-Fernandez, Maria Jesus, Guardia-Olmos, Joan, \& Pero-Cebollero, Maribel. (2013). Qualitative research in psychology: Misunderstandings about textual analysis. Quality and Quantity, 47(3), 1589-1603.

Cheng, Sealing. (2008). Muckraking and stories untold: Ethnography meets journalism on trafficked women and the U.S. military. Sexuality Research \& Social Policy, 5(4), 6-18.

Coalition Against Trafficking in Women-International. (2005). CATW Annual Report 2005. URL: http://action.web.ca/home/catw/attach/CATWo5NewsletterFinal.pdf [May 29, 2013].

Connelly, Mark Thomas. (1980). The response to prostitution in the Progressive Era. Chapel Hill, NC: University of North Carolina Press.

Crépeau, Francois, \& Nakache, Delphine. (2006). Controlling irregular migration in Canada: Reconciling security concerns with human rights protection. IRPP Choices, 12(1), 1-42.

Criminal Intelligence Services Canada (CISC). (2008). Organized crime and domestic trafficking in persons in Canada: Strategic intelligence brief. URL: http://www.cisc.gc.ca/products _services/domestic_trafficking_persons/document/sib_web_en.pdf [February 27, 2013].

Darroch, Michael, \& Darroch, Gordon. (2010). Losing our census. Canadian Journal of Communication, 35(4), 609-617.

Davis, Michael Cory, (Director). (2004). Sex Traffic. [Film]. Big Motion Pictures and Granada Television [Co-producers]. Government of Canada: Canadian Broadcasting Corporation.

Department of Foreign Affairs and International Trade (DFAIT). (2013). Human trafficking and migrant smuggling. URL: http://www.international.gc.ca/crime/human-traf-personne.aspx [June 19, 2013].

Department of Justice. (2013). What is human trafficking? URL: http://www.justice.gc.ca/eng/cjjp/tp/what-quoi.html [June 18, 2013].

Ditmore, Melissa. (2005). Trafficking in lives: How ideology shapes policy. In K. Kempadoo, J. Sanghera, \& B. Pattanaik (Eds.), Trafficking and prostitution reconsidered: New perspectives on migration, sex work, and human rights (pp. 107-126). Boulder, CO: Paradigm Publishers.

Ditmore, Melissa, Maternick, Anna, \& Zapert, Katherine. (2012). The road north: The role of gender, poverty and violence in trafficking from Mexico to the U.S. URL: http://sexworkersproject.org /downloads/2012/swp-2012-the-road-north-en.pdf [August 5, 2013].

Dobrowolsky, Alexandra. (2008). Interrogating 'invisibilization' and 'instrumentalization':Women and current citizenship trends in Canada. Citizenship Studies, 12(5), 465-479.

Doezema, Jo. (2000). Loose women or lost women? The re-emergence of the myth of white slavery in contemporary discourses of trafficking in women. Gender Issues, 18(1), 23-50.

Doezema, Jo. (2001). Ouch! Western feminists' "wounded attachment" to the "third world prostitute." Feminist Review, 67, 16-38.

Donovan, Brian. (2006). White slave crusades: Race, gender, and anti-vice activism, 1887-1917. Chicago, IL: University of Illinois Press.

Edwards, Linda H. (2010). Once upon a time in law: Myth, metaphor, and authority. Tennessee Law Review, 77, 883-916.

Empower Foundation. (2012). Hit and run: Sex worker's research and anti-trafficking in Thailand. Bangkok, Thailand: RATS-W Team and Empower Foundation.

England, Jennifer. (2004). Disciplining subjectivity and space: Representation, film and its material effects. Antipode, 36(2), 295-321.

Foucault, Michel. (1991a). Discipline and punish: The birth of a prison. London, U.K.: Penguin Books. 
Foucault, Michel. (1991b). Governmentality. In G. Burchell, C. Gordon, \& P. Miller (Eds.), The Foucault effect: Studies in governmentality (pp. 87-104). Chicago, IL: University of Chicago Press.

Gamson, William A. (1992). Talking politics. Cambridge, U.K.: Cambridge University Press.

Global Alliance Against Traffic in Women (GAATW). (2011). What's the cost of a rumour? A guide to sorting out the myths and the facts about sporting events and trafficking. URL: http://www.gaatw.org/publications/WhatstheCostofaRumour.11.15.2011.pdf [May 27, 2013].

Government of Canada. (2005). Criminal Code of Canada, c. C-46. s. 279.01 - 279.04. Justice Laws. URL: http://laws-lois.justice.gc.ca/eng/acts/C-46/page-143.html\#h-84 [June 5, 2013].

Hajer, Maarten, \& Laws, David. (2006). Ordering through discourse. In M. Moran, M. Rein, \& R. E. Goodin (Eds.), The Oxford handbook of public policy (pp. 251-268). New York, NY: Oxford University Press.

Harding, Robert. (2006). Historical representations of Aboriginal people in the Canadian news media. Discourse \& Society, 17(2), 205-235.

Hunt, Sarah. (2010). Colonial roots, contemporary risk factors: A cautionary exploration of the domestic trafficking of Aboriginal women and girls in British Columbia, Canada. Alliance News, 33, 27-31.

Hunt, Sarah. (2013). Decolonizing sex work: Developing an intersectional Indigenous approach. In E. van der Meulen, E.M. Durisin, \& V. Love (Eds.), Selling sex: Experience, advocacy, and research on sex work in Canada (pp. 82-100). Vancouver, BC: University of British Columbia Press.

Hunt, Sarah. (2014, forthcoming). Representing colonial violence: Trafficking, sex work, and the violence of law. Atlantis: Critical Studies in Gender, Culture \& Social Justice, 37(2).

Jalali, Rita. (2013). Financing empowerment? How foreign aid to Southern NGOs and social movements undermines grass-roots mobilization. Sociology Compass, 7(1), 55-73.

Jeffrey, Lesley Ann. (2005). Canada and migrant sex-work: Challenging the "foreign" in foreign policy. Canadian Foreign Policy, 12(1), 33-48.

Jessop, Bob. (1990). State theory: Putting the capitalist state in its place. Cambridge, U.K.: Polity Press.

Jiwani, Yasmin, \& Young, Mary Lynn. (2006). Missing and murdered women: Reproducing marginality in news media. Canadian Journal of Communication, 31(2006), 895-917.

JJ. (2013). We speak for ourselves: Anti-colonial and self-determined responses to young people involved in the sex trade. In E. van der Meulen, E.M. Durisin, \& V. Love (Eds.), Selling sex: Experience, advocacy, and research on sex work in Canada (pp. 74-81). Vancouver, BC: University of British Columbia Press.

Justicia for Migrant Workers (J4MW). (2013). Homepage. URL: http://www.justicia4migrantworkers.org/ [August 5, 2013].

Keilholz, Doerthe. (2008). Will Olympics be magnet for human traffickers? The Tyee. URL: http://thetyee.ca/News/2008/o9/o4/HumanTraffic/?utm_source=daily\&utm_medium =e mail\&utm_campaign $=040908$ [August 24, 2013].

Kempadoo, Kamala. (2001). Women of color and the global sex trade: Transnational feminist perspectives. Meridians: Feminism, Race, Transnationalism, 1(2), 28-51.

Lepp, Annalee. (2013). Repeat performance? Human trafficking and the 2010 Vancouver Olympic and Paralympic Games. In E. van der Meulen, E.M. Durisin, \& V. Love (Eds.), Selling sex: Experience, advocacy, and research on sex work in Canada (pp. 251-268). Vancouver, BC: University of British Columbia Press.

Macklin, Audrey. (2003). Dancing across borders: Exotic dancers, trafficking, and Canadian immigration policy. The International Migration Review, 37(2), 464-500.

Maggie's: Toronto Sex Workers Action Project. (2013). About. URL: http://maggiestoronto.ca/about [August 5, 2013].

Malarek, Victor. (2003). The Natashas: Inside the global sex trade. New York, NY: Viking Books.

Malarek, Victor. (2009). The johns: Sex for sale and the men who buy it. Toronto, ON: Key Porter.

McDonald, Lynn, \& Timoshkina, Natalya. (2004). Examining service needs of trafficked women from the former Eastern Bloc: The Canadian case. Journal of Social Work Research and Evaluation, 5(2), 169-192. 
McKay, Ian, \& Swift, Jamie. (2012). Warrior nation: Rebranding Canada in an age of anxiety. Toronto, $\mathrm{ON}$ : Between the Lines.

McNeil, Greg. (2009, June 8). Why conference to discuss issues women face. Cape Breton Post. URL: http://www.capebretonpost.com/Justice/2009-06-08/article-774896/Why-Conference-todiscuss-issues-women-face/1 [July 23, 2013].

Mohanty, Chandra Talpade. (1984). Under Western eyes: Feminist scholarship and colonial discourses. Boundary, 12(3)\& 13(1), 333-358.

NASHI. (2013). Our mission statement. URL: http://www.nashi.ca/home.html [June 19, 2013].

Nelson, Joyce. (2013). The Harper government's war on science. The CCPA Monitor. URL: http://www.policyalternatives.ca/publications/monitor/harper-governments-war-science [September 5, 2013].

No One Is Illegal-Toronto (NOII-Toronto). (2013). Homepage. URL: http://toronto.nooneisillegal.org/ [August 5, 2013].

O'Connell Davidson, Julia. (2005). Children in the global sex trade. Cambridge, U.K.: Polity Press.

O'Connell Davidson, Julia. (2011). Moving children? Child trafficking, child migration, and child rights. Critical Social Policy, 31(3), 454-477.

Ogrodnik, Lucie. (2010). Towards the development of a national data collection framework to measure trafficking in persons. Statistics Canada Catalogue number 85-561-MWE2010021. URL: http://www.statcan.gc.ca/pub/85-561-m/85-561-m2010021-eng.pdf [August 5, 2013].

Oxman-Martinez, Jacqueline, \& Hanley, Jill. (2004). A follow-up study of Canadian policy on human trafficking: Impacts of the Immigration and Refugee Protection Act. URL: http://im .metropolis.net/research-policy/research_content/doc/oxman-martinez\%2otrafic.pdf [August 5, 2013].

Oxman-Martinez, Jacqueline, Lacroix, Marie, \& Hanley, Jill. (2005). Victims of trafficking in persons: Perspectives from the Canadian community sector. Department of Justice URL: http://www.justice.gc.ca/eng/rp-pr/cj-jp/tp/rro6_3/rro6_3.pdf [August 5, 2013]

PACT-Ottawa. (2013a). Guiding principles. URL: http://www.pact-ottawa.org/principles.html [June $19,2013]$.

PACT-Ottawa. (2013b). End slavery day. URL: http://www.pact-ottawa.org/end-slavery-day2013.html [June 19, 2013].

PACT-Ottawa. (2013c). End slavery day 2011. URL: http://www.pact-ottawa.org/end-slavery-day2011.html [June 19, 2013].

People's Law School. (2010). Human trafficking in Canada, $2^{\text {nd }}$ edition. URL: http://www.publiclegaled.bc.ca/uploads/51/e2/51e2egb456c0342bd6378c836568ob6c/English_HumanTrafficking-In-Canada_2010.pdf [June 18, 2013].

Perrin, Benjamin. (2010). Invisible chains: Canada's underground world of human trafficking. Toronto, ON: Penguin Group.

Polaris Project. (n.d.). Human trafficking statistics. URL: http://www.cicatelli.org/titlex/downloadable /Human\%2OTrafficking\%20Statistics.pdf [August 24, 2013].

Poulantzas, Nicos. (1980). State, power, socialism. London, U.K.: Verso.

Project 417. (2013). What is human trafficking? [Video, slide 4] URL: http://project417.com/project417 [June 19, 2013].

Public Safety Canada. (2012). National action plan to combat human trafficking. URL: http://www.publicsafety.gc.ca/cnt/rsrcs/pblctns/ntnl-ctn-pln-cmbt/index-eng.aspx [May 29, 2013].

Roots, Katrin, \& De Shalit, Ann. (2014, forthcoming). Evidence that evidence doesn't matter: Human trafficking cases in Canada. Atlantis: Critical Studies in Gender, Culture \& Social Justice, 37(2).

Rosen, Ruth. (1982). The lost sisterhood: Prostitution in America, 1900-1918. Baltimore, MD: The Johns Hopkins University Press.

Royal Canadian Mounted Police (RCMP). (2013). Project SAFEKEEPING: Domestic human trafficking for sexual exploitation in Canada. Ottawa, ON: The Human Trafficking National Coordination Centre. 
Ruckert, Arne, \& Labonté, Arnold. (2012). The global financial crisis and health equity: Toward a conceptual framework. Critical Public Health, 22(3), 267-279.

Sex Professionals of Canada (SPOC). (2013). Homepage. URL: http://www.spoc.ca/ [August 5, 2013]. Sharma, Nandita. (2005). Anti-trafficking rhetoric and the making of a global apartheid. NWSA Journal, 17(3), 88-111.

Siddiqui, Haroon. (2011, February 20). Country pays when Harper gets his way. The Toronto Star, A19. Sikka, Annette. (2009). Trafficking of Aboriginal women and girls in Canada. URL: http://iog.ca/wpcontent/uploads/2012/12/May-2009_trafficking_of_aboriginal_women-1.pdf [June 5, 2013].

Sircar, Oishik. (2011). Beyond compassion: Children of sex workers in Kolkata's Sonagachi. Childhood, 18(3), 333-349.

Smith, Joy. (2010, March 2). Seamy side to Olympics Canada's shame. Winnipeg Free Press. URL: http://www.winnipegfreepress.com/opinion/analysis/seamy-side-to-olympics-canadasshame-85937627.html [August 24, 2013].

Soderlund, Gretchen. (2005). Running from the rescuers: New U.S. crusades against sex trafficking and the rhetoric of abolition. NWSA Journal, 17(3), 64-87.

Stanley, Brandi. (2009). Sensationalism and its detrimental effect on the anti-human trafficking movement: A call to a critical examination of "abolitionist" rhetoric. Contemporary Slavery and Human Trafficking [Course material]. Josef Korbel School of International Studies, University of Denver, Denver, CO.

Stella. (2013). Making space for working women. URL: http://www.chezstella.org/stella/?q=en /10years [August 5, 2013].

Stiehm, Judith Hicks. (1982). The protected, the protector, the defender. Women's Studies International Forum, 5(3/4), 367-376.

Strauss, Anselm L., \& Corbin, Juliet M. (1990). Basics of qualitative research: Grounded theory procedures and techniques. Newbury Park, CA: Sage Publications.

Surrey Women's Centre. (2013). Working together to combat human trafficking. URL: http://surreywomenscentre.ca/news/2013/o3/working-together-combat-human-trafficking [June 18, 2013].

Vancouver Sun. (2007). Coalition pushes for legal brothel during Olympics. URL: http://www.canada .com/topics/news/national/story.html?id = 4d 44a6a 9 -ea $7 f-4 d d d-913 d-$ 5a1101fcobf $4 \& \mathrm{k}=72145$ [August 24, 2013].

van Dijk, Teun A. (2003). Critical discourse analysis. In D. Schiffrin, D. Tannen, \& H. E. Hamilton (Eds.), The handbook of discourse analysis (pp. 352-371). Malden, MA: Blackwell Publishing Ltd.

van Liempt, Ilse. (2011). Different geographies and experiences of "assisted" types of migration: A gendered critique on the distinction between trafficking and smuggling. Gender, Place and Culture, 18(2), 179-193.

Walia, Harsha. (2010). Transient servitude: Migrant labour in Canada and the apartheid of citizenship. Race \& Class, 52(1), 71-84.

Wallace, Kathleen. (2010, February 2). Human trafficking alive and well for the 2010 Olympics. Vancouver Observer. URL: http://www.vancouverobserver.com/politics/commentary /2010/02/o2/human-trafficking-alive-and-well-2010-olympics [August 24, 2013].

Weitzer, Ronald. (2012). Sex trafficking and the sex industry: The need for evidence-based theory and legislation. The Journal of Criminal Law \& Criminology, 101(4), 1337-1369.

Wijers, Marjan, \& van Doorninck, Marieke. (2002). Only rights can stop wrongs: A critical assessment of anti-trafficking strategies. Paper presented at EU/IOM STOP European Conference on Preventing and Combating Trafficking in Human Beings, September 18-20, 2002. Brussels, Belgium. URL: http://www.walnet.org/csis/papers/wijers-rights.html .

Women's Support Network of York Region. (2013). Human trafficking program. URL: http:// www.womenssupportnetwork.ca/Definition.htm [June 18, 2013].

Yadama, Gautam N. (1997). Tales for the field: Observations on the impact of nongovernmental organizations. International Social Work, 40, 145-162.

Zhang, Sheldon X. (2009). Beyond the 'Natasha' story: A review and critique of current research on sex trafficking. Global Crime, 10(3), 178-195. 